\title{
Detergent formulations for wool domestic washings containing immobilized enzymes
}

\author{
Andreia Vasconcelos · Carla J. S. M. Silva • \\ Marc Schroeder • Georg M. Guebitz • \\ Artur Cavaco-Paulo
}

Received: 17 October 2005 / Accepted: 3 February 2006/ Published online: 24 May 2006

(C) Springer Science+Business Media B.V. 2006

\begin{abstract}
The stability of immobilized and native Esperase, a commercial serine protease, was studied by incubating the enzymes in four formulations containing the same amount of anionic and non-ionic surfactants. The results show that the activity of the immobilized enzyme is not affected by the presence of detergents while the native enzyme lost $50 \%$ of activity after $20 \mathrm{~min}$ of incubation in these four formulations. The washing performance of the detergents prepared with the immobilized Esperase was studied on cotton and wool fabric samples stained with human blood and egg yolk, using as control the detergent containing native Esperase. The best stain removal for cotton samples stained with human blood was achieved using the detergent with immobilized Esperase. Several physical tests confirmed that wool keratin was not degraded by the immobilized Esperase, validating the ability to use formulated detergents containing this immobilized enzyme for safe wool domestic washing.
\end{abstract}

\footnotetext{
A. Vasconcelos · C. J. S. M. Silva ·

A. Cavaco-Paulo ( $\square)$

Department of Textile Engineering, Minho

University, 4800-058 Guimarães, Portugal

e-mail: artur@det.uminho.pt

M. Schroeder · G. M. Guebitz

Department of Environmental Biotechnology,

Graz University of Technology, Graz, Austria
}

Keywords Detergents - Eudragit · Immobilization $\cdot$ Serine proteases $\cdot$ Stain removal $\cdot$ Wool

\section{Introduction}

Proteases constitute the most important group of industrial enzymes and their major application is the detergent industry. Biological detergents are commonly used in domestic laundry because the enzymes they contain provide the added benefit of low temperature washes with improved cleaning performance. Addition of proteases to detergents considerably increases the cleaning effect by removing protein stains such as blood and egg, and increases the consumption of surface-active substances thereby decreasing the pollution load (Moreira et al. 2002; Grebeshova 1999). However, in addition to their ability to remove protein stains, proteases can also hydrolyse natural protein fibres such as wool keratins and silk causing severe and irreversible damage to the garments (Cortez et al. 2005; Shen et al. 1999). For this reason, the immobilization of proteases in soluble matrices could be a way of controlling the enzyme hydrolysis process (Heine and Höcker 1995) and overcome common problems of heterogeneous reaction systems like the poor contact between the insoluble substrate (wool) and the immobilized 
enzyme as well as the incomplete separation of the immobilized enzyme from unreacted solid substrates (Fujimura et al. 1987; Taniguchi et al. 1989).

Available important proteases in commercial detergents are Subtilisin Carlsberg, Subtilisin BPN, Alcalase, Esperase and Savinase. All these enzymes are stable in the presence of various components of detergents and are active at normal washing temperatures and $\mathrm{pH}$ (Moreira et al. 2002; Gupta et al. 1999). Proteases should also be stable in the presence of oxidizing agents, surfactants, bleachers and other additives that might be present in the detergent formulation (Moreira et al. 2002; Greene et al. 1996).

Incorporation of enzymes into detergent formulations can lead to several difficulties. Proteases are susceptible to autolytic degradation, oxidation and denaturation. These processes are often enhanced by surfactants, bleachers and water-softening builders which must be included in any laundry detergent (Stoner et al. 2004; Crutzen and Douglas 1999). Proteases also catalyse the degradation of other additives present in the formulation. In powder formulation this problem can be resolved by isolating the enzyme in separate particles. In liquid formulations the physical isolation of enzymes is more difficult and the presence of water amplifies the detrimental effect of surfactants and enhances the rate of undesirable reactions (Stoner et al. 2004; Lalonde et al. 1995). To overcome this problem, chemical additives are added to the formulations. The combination of carboxylic acid salts and calcium chloride can protect against protease degradation (Stoner et al. 2004; Crossin 1989). Boron compounds (boric acid, borate salts) in conjunction with polyols (propylene glycol, glycerol) also have been shown to stabilize enzymes in liquid detergent formulations (Stoner et al. 2004).

In the present work, the stability and washing performance of different detergent formulations containing enzymes was studied. A commercial protease, Esperase, was added to the formulations, either in the native or immobilized form. This immobilized enzyme can be used in the liquid state covalently linked to a soluble-insoluble polymer.

\section{Material and methods}

Enzyme, reagents and textile materials

The enzyme used in this study was the alkaline serine protease Esperase, a commercial subtilisin (E.C.3.4.21.62) purchased from Sigma. Eudragit S-100 (MW 135,000 composed by 1:2 copolymer of methacrylic acid and methyl methacrylate) a commercial product from Rhöm Pharma was a generous gift from Degussa-Hüls, S.A., Barcelona. Carbodiimide hydrochloride (EDC) and ethanolamine were purchased from Sigma (St. Louis, USA). The surfactants used, Lutensit ALBN 50 and Lutensol ON 70, anionic and nonionic respectively, were provided by BASF. All other chemicals used were of analytical grade.

The textile materials used were $100 \%$ wool fabric and scoured $100 \%$ white cotton fabric. Wool was pre-treated with Lutensol ON 30 (non-ionic surfactant) $1 \mathrm{~g} / \mathrm{l}$ in a bath ratio $1: 20$, at $\mathrm{pH} 9.0\left(\mathrm{Na}_{2} \mathrm{CO}_{3}\right.$ $0.1 \mathrm{M}$ and $\mathrm{NaHCO}_{3} 0.1 \mathrm{M}$ buffer), for $30 \mathrm{~min}$, at $40^{\circ} \mathrm{C}$, on Rota-wash. After the washing procedure, the surfactant was removed from the fabric first with tap water, followed by distilled water. Thereafter, wool was immersed in a bath (same bath ratio) with $1 \% \mathrm{H}_{2} \mathrm{O}_{2}$ (equivalent to $0.52 \mathrm{ml}$ of peroxide $34 \%(1.131 \mathrm{~g} / \mathrm{ml})$ per $20 \mathrm{~g}$ wool $)$, at $\mathrm{pH}$ $9.0\left(\mathrm{Na}_{2} \mathrm{CO}_{3} 0.1 \mathrm{M}\right.$ and $\mathrm{NaHCO}_{3} 0.1 \mathrm{M}$ buffer $)$, for $1 \mathrm{~h}$ at $55^{\circ} \mathrm{C}$, on Rota-wash machine.

Enzyme assay and gel electrophoresis

The activity of proteases was measured according to Silva et al. (2004) using casein as substrate. One unit of activity is defined as the amount of enzyme that hydrolyses casein to produce equivalent colour to $1 \mu \mathrm{mol}$ of tyrosine, per minute, at $\mathrm{pH} 7.5$ and $37^{\circ} \mathrm{C}$.

SDS-PAGE was carried out using the Hoefer miniVe system from Amersham Pharmacia Biotech. The resolving gels $(10 \%$ acrylamide of about $1.5 \mathrm{~mm}$ thickness) were run at a constant voltage $(120 \mathrm{~V})$ and prepared according to the method described by Laemmli (1970). Proteins were visualized by silver staining using Phosphorylase b (97 kDa), Albumin (66 kDa), Ovalbumin (45 kDa), Carbonic Anhydrase (30 kDa), Trypsin inhibitor $(20.1 \mathrm{kDa})$ and $\alpha$-lactalbumin (14.4 $\mathrm{kDa}$ ) for calibration. 
Immobilization and operational stability

The protease was covalently linked to Eudragit S-100 by the carbodiimide coupling by following a protocol described in Silva et al. (2006). For the determination of stability the native and immobilized enzymes were placed in a water bath at 40 or $60^{\circ} \mathrm{C}$ and $100 \mathrm{rpm}$ of stirring and the remaining activity was measured after $3 \mathrm{~h}$ of incubation at this temperature.

\section{Detergent formulation}

The detergents formulations were prepared according to Table 1 . The blended surfactants comprised $34 \%$ of the total formulation weight. The surfactants were then dissolved in 0.3 M Tris-

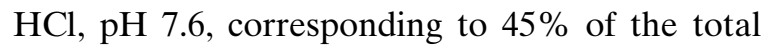
formulation weight. The $21 \%$ remaining formulation space available is for the other additives as shown in Table 1. The experiments were done with $30 \mathrm{U}$ of native and immobilized esperase, which were added prior to the experiments.

The stability of the native and immobilized enzyme in the presence of detergents was determined by incubating the enzyme ( $30 \mathrm{U})$ with a $0.5 \%$ solution of the different detergent formulations solutions, in a water bath at $40^{\circ} \mathrm{C}$ and $80 \mathrm{rpm}$ of stirring for $3 \mathrm{~h}$.

\section{Washing tests}

The performance of native and immobilized protease as a detergent additive was studied with wool and white cotton fabrics $\left(4 \times 4 \mathrm{~cm}^{2}\right)$ stained with human blood and egg. The stains on the samples were made by placing the same amount of blood and egg yolk $(100 \mu \mathrm{l})$ on the surface of the sample. The samples were then left at room temperature for $6 \mathrm{~h}$ in order to dry the stains. The stained samples were then washed with a $0.5 \%$ solution of detergent, detergent and $30 \mathrm{U}$ of immobilized enzyme and detergent and $30 \mathrm{U}$ of native enzyme, for $30 \mathrm{~min}$ in a water bath at $40^{\circ} \mathrm{C}$ and $80 \mathrm{rpm}$ of stirring.

Tensile strength resistance and dimensional stability

Wool fibres were subjected to tensile strength tests according to the ASTM method D50035s90.Wool fabric shrinkage was determined after one 7A and five 5A wash cycles according to Woolmark method TM31 in the ElectroluxWascator machine.

\section{Colour measurements}

The colour of the dyed fabrics was evaluated using a reflectance measuring Datacolour apparatus at standard illuminant D65 (LAV/Spec. Incl., d/8, $\left.\mathrm{D} 65 / 10^{\circ}\right)$. Data were evaluated according to the Kubelka-Munk relationship $K / S$ where $K$ is an adsorption coefficient and $S$ is a scattering coefficient. Three areas on each sample were measured in various positions, and the results represent average values with up to $1 \%$ variation.

\section{Weight loss}

Wool fabrics were conditioned at $100^{\circ} \mathrm{C}$ for $2 \mathrm{~h}$, desiccated and weighted until constant weight (considered as differences between successive weights inferior to $1 \mathrm{mg}$ ). Assays were performed in duplicate.

Table 1 Composition of the detergent formulations used in this study

\begin{tabular}{|c|c|c|c|c|}
\hline Component & Formulation 1 & Formulation 2 & Formulation 3 & Formulation 4 \\
\hline Lutensit A-LBN50 (g) & 10.5 & 10.5 & 10.5 & 10.5 \\
\hline Lutensol ON70 (g) & 6.5 & 6.5 & 6.5 & 6.5 \\
\hline $0.3 \mathrm{M}$ Tris- $\mathrm{HCl}, \mathrm{pH} 7.6(\mathrm{ml})$ & 22.5 & 22.5 & 22.5 & 22.5 \\
\hline $0.5 \mathrm{M}$ Sucrose $(\mathrm{ml})$ & 0 & 10.5 & 0 & 0 \\
\hline $0.01 \mathrm{M}$ EDTA (ml) & 0 & 0 & 1.5 & 0 \\
\hline $0.1 \% \mathrm{CaCl}_{2}(\mathrm{~g})$ & 0 & 0 & 0 & 0.5 \\
\hline $3 \%$ Borax $(\mathrm{g})$ & 0 & 0 & 0 & 2.0 \\
\hline $5 \%$ Sorbitol $(\mathrm{g})$ & 0 & 0 & 0 & 3.5 \\
\hline $\mathrm{H}_{2} \mathrm{O}(\mathrm{ml})$ & 10.5 & 0 & 9.0 & 4.5 \\
\hline
\end{tabular}


SEM pictures

Scanning electron microscopy (SEM) pictures were obtained in the model Leica S360 with a backscattered and secondary electron detector.

\section{Results and discussion}

The major drawback of wool domestic washing is the irreversible damage caused by the hydrolytic degradation of wool keratin by proteases. In this work wool degradation by native and immobilized enzymes was compared under severe conditions. After treatment of $72 \mathrm{~h}$ with $100 \mathrm{U}$ of both enzymes, at $40^{\circ} \mathrm{C}$, with $90 \mathrm{rpm}$ of stirring wool fibres were completely degraded (Figs. 1 and 2).

Wool samples treated with immobilized enzyme retained $76 \%$ of the initial tensile strength while those treated with native enzyme only retained $37 \%$. These results are in accordance with data previously reported (Silva et al. in press). Wool samples treated with immobilized Esperase achieved around $8 \%$ of shrinkage whereas the samples treated with native enzyme showed approximately $7 \%$ of shrinkage. Immobilized Esperase is unable to penetrate the fibre; it only removes partially the cuticle from the fibre surface which is responsible for the shrinkage effect (Heine and Höcker 1995; Feughelman 1997). On the other hand, the native enzyme can penetrate into the fibre, which lead to the total degradation

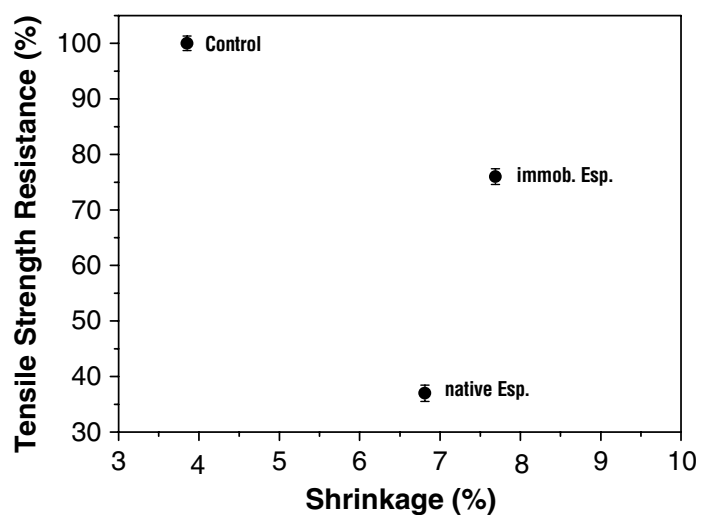

Fig. 1 Tensile strength resistance (\%) and shrinkage (\%) obtained for the wool fabrics treated with immobilized and native enzyme and without enzymatic treatment (control) and therefore to a drastic decrease of the tensile strength.

These results were confirmed with SEM pictures (Fig. 2) where the degradation of wool fibres caused by the native enzyme can be clearly seen (Fig. 2b). The results of Table 2 related to the weight loss of samples are also in accordance with the previous results. It was observed that the samples treated with native enzyme showed a higher weight loss than the samples treated with immobilized Esperase.

The immobilized enzyme retained all of its activity after $3 \mathrm{~h}$ of incubation at $40^{\circ} \mathrm{C}$, both in solution without the detergent and in the detergent formulations (Table 3). The native enzyme lost $50 \%$ of its activity after approximately 20 min of incubation, when present in the detergent formulations. The control (native enzyme alone) lost $50 \%$ of activity only after 131 min of incubation. For the immobilized enzyme there was no difference between the four detergent formulations. The same was true for the native enzyme, although, for the formulation 4 (F4) the half-life time was slightly higher (around $30 \mathrm{~min}$ ). This could mean that the additives used in this formulation increased the stability of the native Esperase in the presence of detergents.

Previous studies demonstrated a direct relationship between measured protease activity within liquid detergent formulations and the observed protease degradation rate (Stoner et al. 2004; Lalonde et al. 1995). These authors concluded that autolysis was the primary mechanism of protease activity loss over time. To establish if this was the case in our detergent formulations, a detergent sample containing native and immobilized enzyme (30 U) was incubated at $40^{\circ} \mathrm{C}$ for $3 \mathrm{~h}$ in a water bath with $80 \mathrm{rpm}$ of stirring. The samples were then analysed using sodium dodecyl sulfate polyacrylamide gel electrophoresis (SDSPAGE).

As shown in Fig. 3, the bands corresponding to the immobilized enzymes are diffuse and appear in the beginning of the resolving gel, confirming their high molecular weight. Since no bands of smaller molecular weight appeared in the gel, we can assume that there was no autolysis of these samples. 

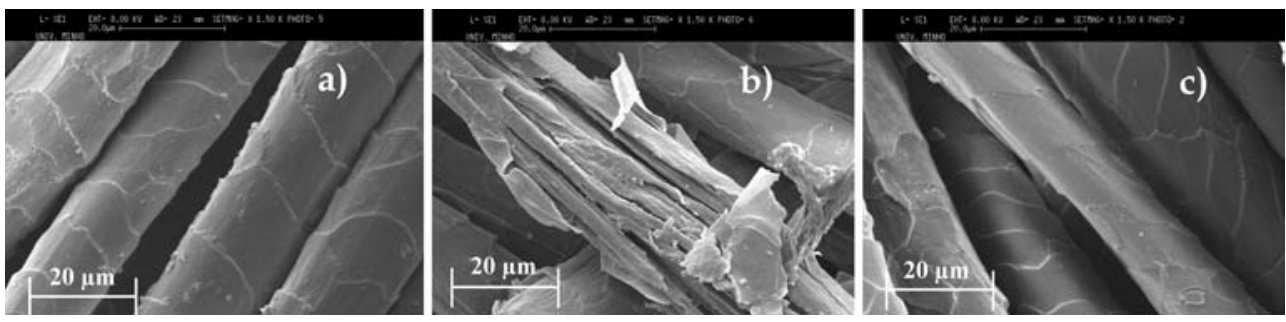

Fig. 2 SEM pictures of wool samples (original magnification: $\times 1500)$. All samples were pre-treated with surfactant (a) and afterwards treated with native (b) and immobilized

Table 2 Weight loss (\%) of wool samples treated with native and immobilized Esperase

\begin{tabular}{lc}
\hline Enzyme & Weight loss (\%) \\
\hline Control (no enzyme) & $1.40 \pm 0.05$ \\
Native Esperase & $17.2 \pm 0.5$ \\
Immobilized Esperase & $4.4 \pm 0.5$ \\
\hline
\end{tabular}

Table 3 Half-life times $t_{1 / 2}(\mathrm{~h})$ for the native Esperase in the presence of detergents. The immobilized Esperase did not loose any activity was lost during $3 \mathrm{~h}$ incubation

\begin{tabular}{lc}
\hline Control & $2.2 \pm 0.30$ \\
\hline F1 + Enzyme & $0.36 \pm 0.08$ \\
F2 + Enzyme & $0.34 \pm 0.09$ \\
F3 + Enzyme & $0.32 \pm 0.09$ \\
F4 + Enzyme & $0.40 \pm 0.10$ \\
\hline
\end{tabular}

These results correlate with the half-life time results from Table 3. The same result was obtained for the native enzyme (data not shown), which is not in accordance with the results from Table 3. Therefore, the activity loss observed for the native enzyme in the presence of detergents is not due to autolysis mechanisms but might be due to enzyme denaturation with temperature and also due to the presence of detergents.

Previous results indicate that the optimum temperature for both native and immobilized Esperase was around $70^{\circ} \mathrm{C}$ (Silva et al. in press). A normal domestic washing temperature is $60^{\circ} \mathrm{C}$ for cotton and $40^{\circ} \mathrm{C}$ for wool. As evident from the half-life times listed in Table 4 the immobilized enzyme would easily withstand a common washing cycle at these temperatures without significant loss of activity. Both the native and immobilized enzymes were more stable at $40^{\circ} \mathrm{C}$ (Table 4). (c) Esperase for $72 \mathrm{~h}$ with $100 \mathrm{U}$ of enzyme, at $40^{\circ} \mathrm{C}$ and $90 \mathrm{rpm}$ of stirring

To determine the efficacy of the enzyme for use as a detergent additive, wash performance analysis of cotton and wool samples was carried out with human blood and egg at $40^{\circ} \mathrm{C}$ for $30 \mathrm{~min}$. For the blood stained cotton sample it was observed that the best removal of stain was with the detergent formulation 2 (F2) in the presence of immobilized enzyme (Fig. 4). This formulation contains sucrose, a protein stabilizer, which protects proteins against oxidation, aggregation and damage during lyophilization (Stoner et al. 2004; DePaz et al. 2000; Krishnan et al. 2002; Kendrick et al. 1998; Kreilgaard et al. 1998). For the cotton sample stained with egg the best removal was obtained with the detergent formulation 3 (F3) which contains EDTA in the presence of immobilized enzyme (Fig. 4). Stability of the enzyme in presence of EDTA is essential since an enzyme to be used as a detergent additive should not require a metal cofactor. Detergents contain high amounts of chelating to remove divalent cations responsible for water hardness and enhancing stain removal (Oberoi et al. 2001). Interestingly, blood stains were removed better than eggs stains from cotton fabric although blood penetrates into the fabric more easily. However, the higher protein content of blood might explain these results.

For the wool samples stained with human blood the best stain removal was obtained when the immobilized enzyme was combined with formulation 2 (F2) which contains sucrose (Fig. 5). For the wool samples stained with egg yolk the best removal was achieved in the washing done with detergent formulation 1 (F1) in the presence of immobilized enzyme (Fig. 5). Like with cotton, human blood stains were removed more easily than egg yolk. Nevertheless, both stained wool 


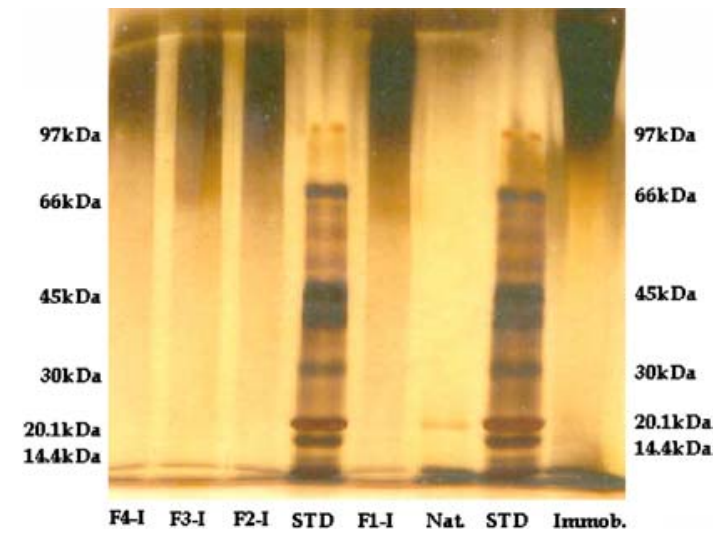

Fig. 3 SDS-PAGE of the immobilized enzyme after the incubation with different detergent solutions for $3 \mathrm{~h}$ in water bath at $40^{\circ} \mathrm{C}$ and $80 \mathrm{rpm}$ of stirring

Table 4 Half-life times $t_{1 / 2}$ (h) for the native and immobilized Esperase at 40 and $60^{\circ} \mathrm{C}$

\begin{tabular}{lrr}
\hline Temperature $\left({ }^{\circ} \mathrm{C}\right)$ & \multicolumn{1}{c}{ Native } & Immobilized \\
\hline 40 & $2.2 \pm 0.30$ & $14.6 \pm 4.9$ \\
60 & $0.58 \pm 0.04$ & $6.9 \pm 0.9$ \\
\hline
\end{tabular}

samples show worse results than the cotton samples. Thus, there was no additional stain removal effect due to limited surface hydrolysis of the protein fibres.

\section{Conclusions}

The use of proteases as additives in detergents is a common practice. However, the domestic washing

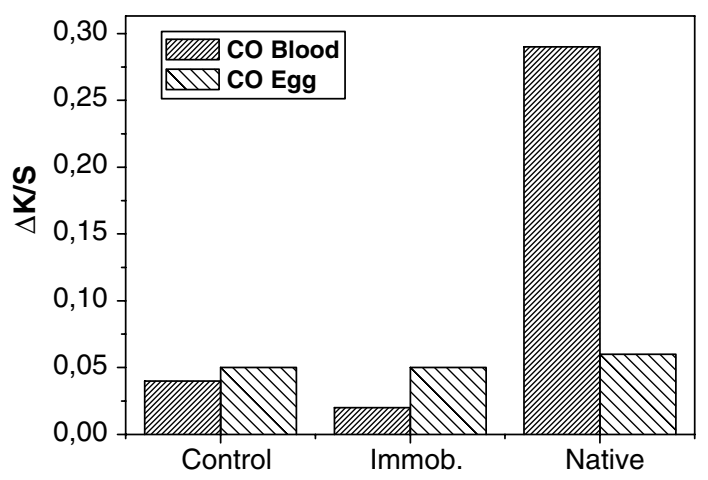

Fig. $4 \Delta \mathrm{K} / \mathrm{S}$ values of cotton samples stained with human blood (CO Blood) and egg yolk (CO Egg) after washing, respectively, with detergent formulations $\mathrm{F} 2$ and $\mathrm{F} 3$ in the presence of immobilized and native enzyme



Fig. $5 \Delta \mathrm{K} / \mathrm{S}$ values of wool samples stained with human blood (Wool Blood) and egg yolk (Wool Egg) after washing, respectively, with detergent formulations F2 and $\mathrm{F} 1$ in the presence of immobilized and native enzyme

of wool or silk goods with these detergents is not safe due to the irreversible damages caused by partial enzymatic hydrolysis of these protein fibres.

In this study, we demonstrated that immobilization of proteases leads to acceptable degrees of weight loss, tensile strength loss and shrinkage of wool fabrics treated under extreme conditions (72 h). On the other hand, the fabric treated with native enzyme showed severe damages on the wool fibres which was confirmed by the SEM pictures. Therefore, the immobilized protease can be considered to be used as additive in formulations of wool domestic detergents. It was also necessary to verify the efficacy of immobilized Esperase on the removal of proteic stains. Thus, wool and cotton fabrics stained with human blood and egg yolk were subjected to simulated washing with several detergents formulations containing immobilized and native enzyme. The immobilized Esperase was more stable in the presence of detergents than the native enzyme. The activity of the immobilized enzyme remained constant after the incubation while the native Esperase lost 50\% of activity after approximately $30 \mathrm{~min}$ of incubation with detergents at $40^{\circ} \mathrm{C}$. It was observed that the best removal was obtained on cotton samples stained with human blood. On wool samples the washing results were worst due to the hydrophobic character of wool fibres.

The stability of immobilized Esperase in the presence of detergents at $40^{\circ} \mathrm{C}$ and the ability to remove stains, demonstrate that this enzyme can 
be used as a detergent additive to improve their washing performance.

\section{References}

Cortez J, Bonner PLR, Griffin M (2005) Transglutaminase treatment of wool fabrics leads to resistance to detergent damage. J Biotechnol 116:379-386

Crossin MC (1989) Protease stabilization by carboxylicacid salts-relative efficiencies and mechanisms. J Am Oil Chem Soc 66:1010-1014

Crutzen A, Douglass ML (1999) Detergent enzymes: a challenge! In: Zoller U, Broze G (eds) Handbook of detergents, Part A: properties. Marcel Dekker, NY, pp 639-690

DePaz RA, Barnett CC, Dale DA, Carpenter JF, Gaertner AL, Randolph TW (2000) The excluding effects of sucrose on a protein chemical degradation pathway: methionine oxidation in subtilisin. Arch Biochem Biophys 384:123-132

Feughelman M (1997) Introduction to the physical properties of wool, hair \& other (- keratin fibres. Mechanical properties and structure of alpha-keratin fibres: wool, human hair and related fibres, UNSW Press,Sydney, pp 1-14

Fujimura M, Mori T, Tosa T (1987) Preparation and properties of soluble-insoluble immobilized proteases. Biotech Bioeng 29:747-752

Grebeshova RN, Saldeco-Torres LE, Hidalgo MA (1999) Serine protease of Bacillus subtilis R. Appl Biochem Microbiol 35:131-134

Greene RV, Griffin I-IL, Cotta MA (1996) Utility of alkaline protease from marine shipworm bacterium in industrial cleansing applications. Biotechnol Lett 18:759-764

Gupta R, Gupta K, Saxena RK, Khan S (1999) Bleachstable alkaline protease from Bacillus sp. Biotechnol Lett 21:135-138

Heine E, Höcker H (1995) Enzyme treatments for wool and cotton. Rev Prog Coloration 25:57-63

Kendrick BS, Carpenter JF, Cleland JL, Randolph TW (1998) A transient expansion of the native state precedes aggregation of recombinant human interferon-gamma. Proc Natl Acad Sci USA 95:1414214146
Kreilgaard L, Frokjaer S, Flink JM, Randolph TW, Carpenter JF (1998) Effects of additives on the stability of recombinant human factor xiii during freeze-drying and storage in the dried solid. Arch Biochem Biophys 360:121-134

Krishnan S, Chi EY, Webb JN, Chang BS, Shan DX, Goldenberg M et al (2002) Aggregation of granulocyte colony stimulating factor under physiological conditions: characterization and thermodynamic inhibition. Biochemistry 41:6422-6431

Laemmli UK (1970) Cleavage of structural proteins during assembly of head of bacteriofage-T4. Nature 227: 680-685

Lalonde J, Witte EJ, Oconnell ML, Holliday L (1995) Protease stabilization by highly concentrated anionic surfactant mixtures. J Am Oil Chem Soc 72:53-59

Moreira KA, Albuquerque BF, Teixeira MFS, Porto ALF, Lima Filho JL. (2002) Application of protease from Nocardiopsis sp. as a laundry detergent additive. World J Microbiol Biochem 18:307-312

Oberoi R, Beg QK, Puri S, Saxena RK, Gupta R (2001) Characterization and wash performance analysis of an SDS-stable alkaline protease from Bacillus sp. World J Microbiol Biotechnol 17:493-497

Shen J, Bishop D, Heine E, Hollfelder B (1999) Some factors affecting the control of proteolytic enzymes reactions on wool. J Tex Inst 90(3):404-411

Silva CJSM, Sousa F, Gübitz G, Cavaco-Paulo A (2004) Chemical modifications on proteins using glutaraldehyde. Food Technol Biotechnol 42(1):51-56

Silva CJSM, Gübitz G, Cavaco-Paulo A (2006) Optimization of a serine protease coupling to Eudragit S-100 by experimental design techniques. J Chem Technol Biotechnol 81:8-16

Stoner MR, Dale DA, Gualfetti PJ, Becker T, Manning M, Carpenter JF, Randolph W (2004) Protease autolysis in heavy-duty liquid detergent formulations: effects of thermodynamic stabilizers and protease inhibitors. Enzyme Microb Technol 34:114-125

Taniguchi M, Kobayashi M, Fujii M (1989) Properties of reversible soluble-insoluble cellulose and its application to repeated hydrolysis of crystalline cellulose. Biotech Bioeng 34:1092-1097 